\title{
Syntheses and Structures of Zinc Bis(iminodiphenylphosphorane)methanide Complexes
}

\author{
Melike Bayram, Sebastian Gondzik, Dieter Bläser, Christoph Wölper, Stephan Schulz ${ }^{*[a]}$
}

Dedication ((optional))

\begin{abstract}
Reactions of bis(phosphinimino)methanes $\mathrm{H}_{2} \mathrm{C}\left(\mathrm{PPh}_{2} \mathrm{NR}\right)_{2}$ $\left(\mathrm{R}=\mathrm{SiMe}_{3} \mathrm{~L}^{1} \mathbf{H}, \mathrm{Ph} \mathbf{L}^{2} \mathbf{H}, 2,6-i-\mathrm{Pr}_{2} \mathrm{C}_{6} \mathrm{H}_{3}\right.$ (Dipp) $\left.\mathbf{L}^{3} \mathrm{H}\right)$ with $\mathrm{ZnR}_{2}(\mathrm{R}=$ $\mathrm{Me}, \mathrm{Et}$ ) yielded the corresponding bis(phosphinimino)methanide zinc complexes $L Z n M e ~\left(L^{2} \mathbf{1}, L^{3} \mathbf{2}\right)$ and $L Z n E t\left(L^{1} \mathbf{3}, L^{2} \mathbf{4}, L^{3} \mathbf{5}\right) .1$ - 5 were characterized by heteronuclear NMR $\left({ }^{1} \mathrm{H},{ }^{13} \mathrm{C},{ }^{31} \mathrm{P}\right)$ and $\mathrm{IR}$ spectroscopy, elemental analysis and single crystal $\mathrm{X}$-ray diffraction.
\end{abstract}

\section{Introduction}

Bis(phosphinimino)methanes $\mathrm{H}_{2} \mathrm{C}\left(\mathrm{PPh}_{2} \mathrm{NR}\right)_{2} \mathrm{I}$, which are easily accessible by the Staudinger reaction or based on the Kirsanov reaction, ${ }^{[1,2]}$ as well as monoanionic bis(phosphinimino)methanides $\left[\mathrm{HC}\left(\mathrm{PPh}_{2} \mathrm{NR}\right)_{2}\right]^{-}$II and dianionic bis(phosphinimino)methanediides $\left[\mathrm{C}\left(\mathrm{PPh}{ }_{2} \mathrm{NR}\right)_{2}\right]^{2-}$ III have been widely applied in the past for the stabilization of main group metal, transition metal complexes and f-element complexes in high and low oxidations states with unusual coordination modes. ${ }^{[3]}$ In addition, Roesky et al. and others demonstrated the promising technical application of various metal complexes in catalysis. ${ }^{[4]}$<smiles>[R]N=P([R])([R])[C@@H]([2H])[PH]([R])([R])=N[R]</smiles><smiles>[R]N=[PH]([R])([R])[C@H](C)[PH]([R])([R])N[R]</smiles><smiles></smiles>

Scheme 1 Structures of neutral bis(phosphinimino)methanes $\mathrm{H}_{2} \mathrm{C}\left(\mathrm{P}\left(\mathrm{Ph}_{2}\right) \mathrm{NR}\right)_{2}$ $\mathrm{I}$, monoanionic bis(phosphinimino)methanides $\left[\mathrm{HC}\left(\mathrm{PPh}_{2} \mathrm{NR}\right)_{2}\right]^{-} \mathrm{II}$ and dianionic bis(phosphinimino)methanediides $\left[\mathrm{C}\left(\mathrm{PPh}_{2} \mathrm{NR}\right)_{2}\right]^{2-}$ III; only one mesomeric form for II and III are shown.

Zinc complexes containing neutral (type I), ${ }^{[5]}$ monoanionic (type II), ${ }^{[5,6]}$ and dianionic ligands (type III), ${ }^{[7]}$ respectively, have been synthesized and structurally characterized and their promising activity in ring-opening polymerization (ROP) of rac-lactide was proven by several research groups. ${ }^{\left[{ }^{[8}\right.}$ These experimental studies also demonstrated that bis(phosphinimino)methanide ligands in such complexes should be rather regarded as noninnocent ligand since they were found to easily react with heterocumulenes with activation of the backbone $\mathrm{CH}$ and subsequent formation of tridentate complexes. ${ }^{[6 a, c]}$

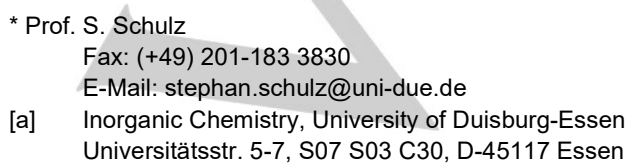

Supporting information for this article is given via a link at the end of the document.
Due to our long standing interest in the synthesis of main group metal and transition metal complexes - in particular zinc complexes - containing $\mathrm{N}, \mathrm{N}^{\prime}$-chelating as well as $\mathrm{N}, \mathrm{O}$-chelating ligands such as amidinate,,$^{[9]}$ â-diketiminate, ${ }^{[10]}$ amidate, ${ }^{[11]}$ and ketiminate ligands, ${ }^{[12]}$ respectively, we recently started to expand these studies on the synthesis of bis(phosphinimino)methanide zinc complexes and demonstrated that bis(phosphinimino)methanide ligands can be used for the stabilization of homoleptic and heteroleptic monovalent zinc complexes of the general type $\mathrm{Cp}^{\star} \mathrm{Zn}-\mathrm{ZnL^{1/2/3 }}$ and $\mathrm{L}^{2} \mathrm{Zn}-\mathrm{ZnL^{2 }}$ containing a central $\mathrm{Zn}-\mathrm{Zn}$ bond. ${ }^{[13]} \mathrm{We}$ now expanded our studies on reactions of bis(phosphinimino)methanes $\mathrm{H}_{2} \mathrm{C}\left(\mathrm{PPh}_{2} \mathrm{NR}\right)_{2}$ with $\mathrm{ZnMe}_{2}$ and $\mathrm{ZnEt}_{2}$ in different molar ratios and different reaction temperatures and report herein on the synthesis and solid state structures of the five heteroleptic bis(phosphinimino)methanide complexes of the general type $\left[\mathrm{HC}\left(\mathrm{PPh}{ }_{2} \mathrm{NR}\right)_{2}\right] \mathrm{ZnMe}$ and $\left[\mathrm{HC}\left(\mathrm{PPh}_{2} \mathrm{NR}\right)_{2}\right] \mathrm{ZnEt}$, respectively.

\section{Results and Discussion}

Reactions of $\mathrm{H}_{2} \mathrm{C}\left(\mathrm{PPh}_{2} \mathrm{NR}\right)_{2}\left(\mathrm{R}=\mathrm{SiMe}_{3} \mathrm{~L}^{1} \mathrm{H}, \mathrm{Ph} \mathrm{L}^{2} \mathrm{H}, 2,6-i-\right.$ $\mathrm{Pr}_{2} \mathrm{C}_{6} \mathrm{H}_{3}$ (Dipp) $\mathbf{L}^{3} \mathrm{H}$ ) with one equivalent of $\mathrm{ZnR}_{2}(\mathrm{R}=\mathrm{Me}, \mathrm{Et})$ yielded the expected heteroleptic complexes $L Z n M e\left(L^{2} 1, L^{3}\right.$ 2) ${ }^{[14]}$ and $L Z n E t\left(L^{1} 3, L^{2} 4, L^{3} 5\right)$ containing the monoanionic bis(phosphinimino)methanide ligand as was expected. Any attempts toward double deprotonation of $\mathrm{H}_{2} \mathrm{C}\left(\mathrm{PPh}_{2} \mathrm{NR}\right)_{2}$ and formation of the dianionic bis(phosphinimino)methanediide ligand failed. The reactions of $\mathrm{H}_{2} \mathrm{C}\left(\mathrm{PPh}_{2} \mathrm{NR}\right)_{2}$ with both one and two equivalents of $\mathrm{ZnMe}_{2}$ and $\mathrm{ZnEt}_{2}$ in boiling toluene for $24 \mathrm{~h}$ as well as in the absence of any solvents at temperatures up to $100{ }^{\circ} \mathrm{C}$ in closed glass tubes for $12 \mathrm{~h}$ only yielded complexes 1 . 5. These findings are in remarkable contrast to those recently observed in analogous reactions of $\mathrm{H}_{2} \mathrm{C}\left(\mathrm{PPh}_{2} \mathrm{NR}\right)_{2}$ with $\mathrm{BeEt}_{2}$, in which depending on the molar ratio either mononuclear bis(phosphinimino)methanides $\left[\mathrm{HC}\left(\mathrm{PPh}_{2} \mathrm{NR}\right)_{2}\right] \mathrm{BeEt}$ or dinuclear bis(phosphinimino)methanediides $\left[\mathrm{C}\left(\mathrm{PPh}_{2} \mathrm{NR}\right)_{2}[\mathrm{BeEt}]_{2}\right.$ were obtained. ${ }^{[15]}$

1 - 5 are soluble in organic solvents such as $n$-hexane, toluene, THF and $\mathrm{Et}_{2} \mathrm{O}$, respectively. ${ }^{1} \mathrm{H}$ and ${ }^{13} \mathrm{C}$ NMR spectra of the complexes show the expected resonances of the bis(phosphinimino)methanide ligand including the resonance for the methanide proton of the ligand backbone $(1.821 ; 1.652$; $1.93 \mathbf{3}, 1.83 \mathbf{4}, 1.64 \mathrm{ppm} \mathbf{5}$ ) as well as the typical resonances of the Zn-bonded methyl (singlets at $0.411 ;-0.59$ ppm 2) and ethyl group (quartets and triplets at $0.95,1.843,1.28,1.864,0.31$, $0.93 \mathrm{ppm} 5$ ) in the expected 1:1 molar ratio. Comparable values were previously reported, i.e. for $\left[\left\{\mathrm{HC}\left(\mathrm{PPh}_{2} \mathrm{NSiMe}_{3}\right)_{2}\right\} \mathrm{ZnMe}\right]$ $(0.17 \mathrm{ppm})^{[6 \mathrm{a}]}$ and $\left[\left\{\mathrm{HC}\left(\mathrm{PPh}_{2} \mathrm{NMes}\right)_{2}\right\} \mathrm{ZnMe}\right]\left(\mathrm{Mes}=2,4,6-\mathrm{Me}_{3-}\right.$ $\left.\mathrm{C}_{6} \mathrm{H}_{2} ;-0.59 \mathrm{ppm}\right),{ }^{[4 a]}$ respectively. Compounds with a planar $\mathrm{CP}_{2} \mathrm{~N}_{2} \mathrm{Zn}$ ring typically show ${ }^{1} \mathrm{H}$ NMR values at higher field, while 
the ${ }^{1} \mathrm{H}$ NMR resonance of non-planar, boat-type $\mathrm{Zn}$ complexes, for which attractive backbone-C $\cdots \mathrm{Zn}$ contacts were discussed, is shifted to lower field. The ${ }^{31} \mathrm{P}$ NMR spectra of $\mathbf{1}-\mathbf{5}$ each exhibit one sharp singlet (23.8 1, 29.4 2, 26.0 3, 23.6 4, 28.9 ppm 5), indicating two equivalent phosphorus atoms, which are shifted downfield compared to the neutral ligands $\left({ }^{31} \mathrm{P}\right.$ NMR $\left(\mathrm{C}_{6} \mathrm{D}_{6}\right)$ : $\left.\mathrm{L}^{1} \mathrm{H}:-5.3 \mathrm{ppm}, \mathrm{L}^{2} \mathrm{H}:-3.3 \mathrm{ppm}, \mathrm{L}^{3} \mathrm{H}:-16.2 \mathrm{ppm}\right)$. The IR spectra of 1 - 5 show strong absorptions between 1240 and $1260 \mathrm{~cm}^{-1}$, which can be ascribed to the $\mathrm{P}=\mathrm{N}$ stretching vibration<smiles>[R]N=P(c1ccccc1)(c1ccccc1)P(=N[R])(c1ccccc1)C(c1ccccc1)[PH]([CH])(C)C[3H]</smiles><smiles>[R]N1PC(c2ccccc2)=P(c2ccccc2)(c2ccccc2)N([R])[Z2]1C</smiles>

$\mathrm{R}=\mathrm{Ph} 1, \mathrm{DIPP} 2$

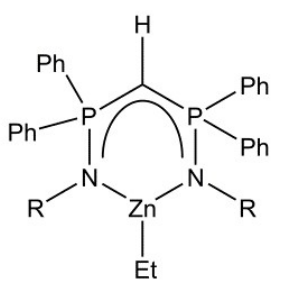

$\mathrm{R}=\mathrm{SiMe}_{3} 3, \mathrm{Ph}$ 4, DIPP 5
Scheme 2 Synthesis of heteroleptic bis(phosphinimino)methanide zinc complexes 1 - 5

Crystals of $\mathbf{1}$ - $\mathbf{5}$ suitable for single crystal X-ray diffraction studies were obtained upon slow re-crystallization from solutions in toluene at ambient temperature $(1,2)$ and $0{ }^{\circ} \mathrm{C}(3)$ or from a solution in thf at $0{ }^{\circ} \mathrm{C}(\mathbf{4}, \mathbf{5}) .3$ crystallizes in the triclinic space group $P-1$ and $\mathbf{5}$ crystallizes in the orthorhombic space group Pbca, while the others belong to the monoclinic crystal system $\left(P 2_{1} / c(\mathbf{1}, \mathbf{4})\right.$ and $P 2_{1} / n(2)$ with $Z^{\prime}=1$ in all cases. Figure 1 and 2 show the solid state structures of 1 and 3 , while those of 2, 4 and $\mathbf{5}$ are given in the electronic supplement.

1 - 5 are monomeric complexes with threefold-coordinated $\mathrm{Zn}$ atoms, which adopt an almost ideal trigonal-planar coordination geometry with the sum of the bond angles close to the ideal value of $360^{\circ}\left(358.8(6)^{\circ} \mathbf{1}, 359.9(3)^{\circ} \mathbf{2}, 358.4(7)^{\circ} \mathbf{3}, 358.0(7)^{\circ} \mathbf{4}\right.$, $\left.360.0(8)^{\circ} 5\right)$. The six-membered $\mathrm{CP}_{2} \mathrm{~N}_{2} \mathrm{Zn}$ metallacycles in 1 - 5 unexceptionally adopt distorted boat-type conformations as was reported for $\mathrm{L}^{1} \mathrm{ZnMe}{ }^{[6]}$ as well as for the homoleptic and heteroleptic $\mathrm{Zn}(\mathrm{I})$ complexes. ${ }^{[13]}$ The $\mathrm{Zn}-\mathrm{N}$ bond lengths in $\mathbf{1}$ - $\mathbf{5}$ range from 1.96 to $2.08 \AA$, which fall exactly within the $Z n-N$ bond lengths range reported for heteroleptic bis(phosphinimino)methanide zinc complexes LZnR (1.93 to $2.08 \AA) \cdot{ }^{[16]}$ The $Z n-N$ bond lengths observed for 2 (1.966(5) $\AA$ ) and 5 (av. 1.971(2) $\AA$ ) containing the sterically most demanding Dipp substituent at the $\mathrm{N}$ atoms exhibit the shortest $\mathrm{Zn}-\mathrm{N}$ bond lengths. They are comparable to those reported for the heteroleptic $\mathrm{Zn}(\mathrm{I})$ complex $C p^{*} Z n-Z n L^{3}$ (av. 1.985(1) $\AA$ ), ${ }^{[13]}$ but significantly shorter compared to those observed for 1 (av. 2.059(2) $\AA$ ), 3 (av. 2.052(2) $\AA$ ) and 4 (av. 2.031(2) $\AA$ ), respectively, whose $\mathrm{Zn}-\mathrm{N}$ bond lengths are comparable to those observed for $L^{1} \mathrm{ZnMe}$ (av. 2.063(2) $\AA)^{[6 a]}$ as well as the homoleptic $\mathrm{Zn}(\mathrm{I})$ complex $\mathrm{L}_{2}{ }_{2} \mathrm{Zn}_{2}$ (av.

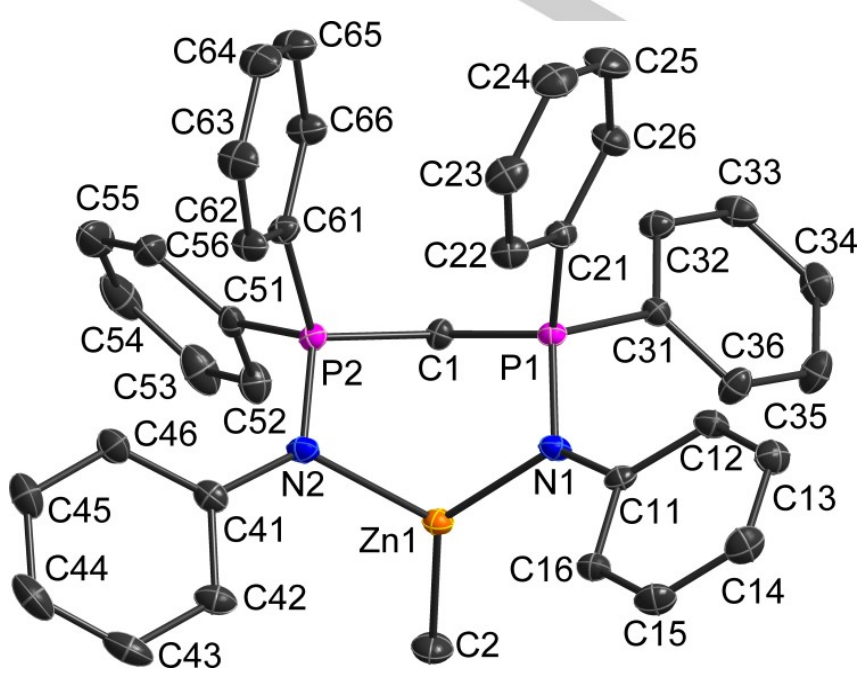

Fig. 1 Solid state structure of $\mathbf{1} ; \mathrm{H}$ atoms are omitted for clarity and thermal ellipsoids are displayed at $50 \%$ probability levels.

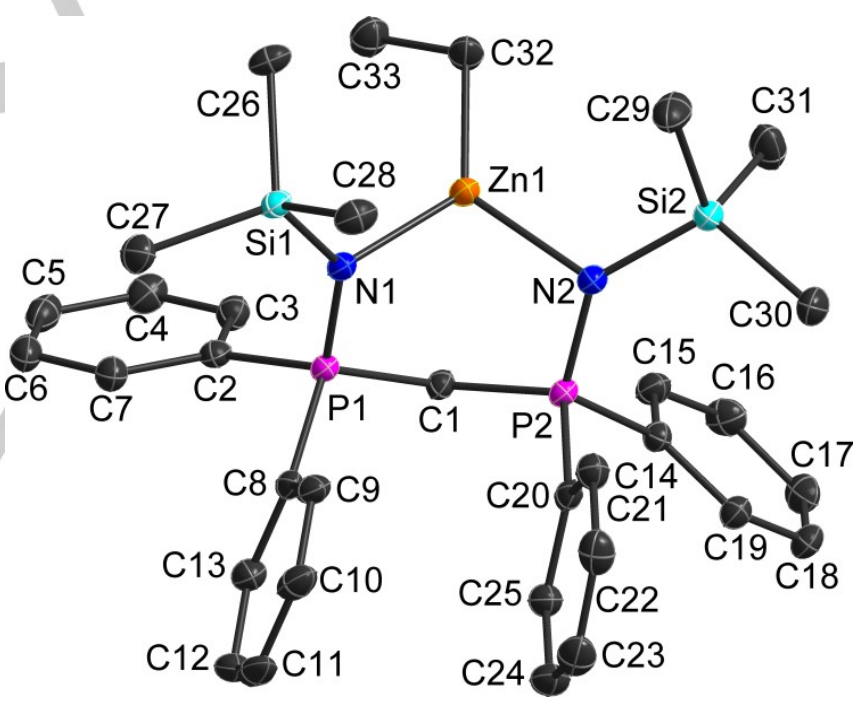

Fig. 2 Solid state structure of 3; $\mathrm{H}$ atoms are omitted for clarity and thermal ellipsoids are displayed at $50 \%$ probability levels.

2.059(2) Å). In addition, zinc complexes $\left[\mathrm{H}_{2} \mathrm{C}\left(\mathrm{PPh}_{2} \mathrm{NSiMe}_{3}\right)_{2} \mathrm{ZnX}{ }_{2} \quad(\mathrm{X}=\mathrm{Cl}, \quad \mathrm{I})\right.$ containing neutral bis(phosphinimino)methane ligands also show comparable $\mathrm{Zn}-\mathrm{N}$ bond lengths (2.03-2.06 $\AA$ ). ${ }^{[5]}$ The comparatively long $\mathrm{Zn}-\mathrm{N}$ bond lengths in 1, 3 and 4 are most likely caused by the well known capability of both the $\mathrm{Ph}$ and the trimethylsilyl groups to stabilize negative charges either by negative hyperconjugation $\left(\mathrm{SiMe}_{3}\right)$ or by resonance delocalization (Ph). In contrast, the shorter $\mathrm{Zn}-\mathrm{N}$ bond lengths in 2 and 5 are caused by the perpendicular orientation of the DIPP substituent in respect to the $\mathrm{P}=\mathrm{N}$ axis, 
Table 1. Central bond lengths $(\AA)$ as well as bond and torsion angles $\left(^{\circ}\right)$ of $\mathbf{1}-\mathbf{5}$ and $\left[\left\{\mathrm{HC}\left(\mathrm{PPh}_{2} \mathrm{NSiMe}\right)_{2}\right\} \mathrm{ZnMe}\right]\left(\mathbf{L}^{1} \mathbf{Z n M e}\right) .^{[6 a]}$

\begin{tabular}{|c|c|c|c|c|c|c|}
\hline & $\mathrm{L}^{1} \mathrm{ZnMe}$ & L'ZnMe 1 & $\mathrm{~L}^{3} \mathrm{ZnMe} 2$ & L'ZnEt 3 & L'ZnEt $4^{2}$ & L'ZnEt 5 \\
\hline Zn1-N1 & 2.083(3) & $2.0417(12)$ & $1.966(5)$ & $2.0668(16)$ & $2.0326(14)$ & $1.9641(16)$ \\
\hline Zn1-N2 & $2.042(3)$ & $2.0759(13)$ & $1.966(5)$ & $2.0375(15)$ & $2.0299(15)$ & $1.9782(16)$ \\
\hline $\mathrm{Zn} 1-\mathrm{C} 1$ & $2.527(4)$ & $2.4985(14)$ & $3.392(6)$ & $2.5897(18)$ & $2.5986(18)$ & $3.3869(19)$ \\
\hline N1-P1 & $1.585(3)$ & $1.6216(12)$ & $1.621(5)$ & $1.5946(15)$ & $1.6167(15)$ & $1.6226(16)$ \\
\hline N2-P2 & $1.600(3)$ & $1.6212(12)$ & $1.628(5)$ & $1.5969(15)$ & $1.6170(16)$ & $1.6220(16)$ \\
\hline P1-C1 & $1.728(4)$ & $1.7271(14)$ & $1.700(5)$ & $1.7319(19)$ & $1.7409(17)$ & $1.696(2)$ \\
\hline $\mathrm{P} 2-\mathrm{C} 1$ & $1.739(4)$ & $1.7325(14)$ & $1.702(5)$ & $1.7449(18)$ & $1.7264(18)$ & $1.698(2)$ \\
\hline N1-Cipso & - & $1.4051(18)$ & $1.435(7)$ & - & $1.396(2)$ & $1.443(3)$ \\
\hline N2-C & - & $1.3971(19)$ & $1.441(7)$ & - & $1.402(2)$ & $1.437(2)$ \\
\hline Zn1-C & $1.958(4)$ & $1.9614(16)$ & $1.947(6)$ & $1.9762(19)$ & $1.9720(19)$ & $1.980(2)$ \\
\hline P1-C1-P2 & $120.1(2)$ & $124.84(8)$ & $130.9(3)$ & $119.90(11)$ & $124.32(10)$ & $134.63(12)$ \\
\hline C1-P1-N1 & $106.8(2)$ & $104.95(7)$ & $112.1(3)$ & $107.22(9)$ & 104.76(8) & 112.04(9) \\
\hline C1-P2-N2 & $110.18(10)$ & $104.65(7)$ & 111.9(3) & $109.34(8)$ & $104.76(8)$ & 111.18(9) \\
\hline $\mathrm{P} 1-\mathrm{N} 1-\mathrm{Zn} 1$ & $110.13(10)$ & $100.96(6)$ & $122.0(3)$ & $100.40(8)$ & $104.65(7)$ & $124.27(9)$ \\
\hline P2-N2-Zn1 & $111.10(10)$ & $100.67(6)$ & $124.6(3)$ & $101.05(8)$ & $103.86(8)$ & 124.51(9) \\
\hline N1-Zn1-N2 & $99.4(1)$ & 103.34(5) & $107.86(19)$ & $101.24(6)$ & $102.88(6)$ & $107.24(6)$ \\
\hline N1-Zn1-C Alkyl & $128.9(2)$ & $133.75(6)$ & $123.3(3)$ & $129.45(7)$ & $127.80(7)$ & 128.81(8) \\
\hline $\mathrm{N} 2-\mathrm{Zn} 1-\mathrm{C}_{\text {Alkyl }}$ & $129.8(2)$ & $121.74(6)$ & $128.7(3)$ & $127.69(8)$ & $127.34(7)$ & 123.94(8) \\
\hline $\mathrm{N}-\mathrm{P} \cdots \mathrm{P}-\mathrm{N}$ & 15.49 & $1.38(7)$ & $17.8(3)$ & $12.7(8)$ & $4.67(8)$ & 14.17(9) \\
\hline
\end{tabular}

[a] These data are given for comparison with the corresponding Et-substituted complex 3 . Standard uncertainties are given whereever available from the original publication, others were calculated from the deposited atomic positions (CCDC-1295755).

which is enforced by repulsive steric interactions with the $i-\mathrm{Pr}$ substituents. This leads to a less effective resonance delocalization and a higher negative charge on $\mathrm{N}$, resulting in shorter $\mathrm{N}-\mathrm{Zn}$ bonds. In contrast, the Ph-substituents at the nitrogen atoms in $\mathbf{1}$ and $\mathbf{4}$ adopt an almost coplanar orientation with the $\mathrm{P}=\mathrm{N}$ axis, leading to an almost perfect delocalization of the $\pi$-electron density and a less negatively charged $\mathrm{N}$ atom, resulting in elongated $\mathrm{Zn}-\mathrm{N}$ bonds. The slightly shorter $\mathrm{N}-\mathrm{C}_{\text {ipso }}$ bond lengths in 1 (av. $1.401 \AA$ ) and 4 (av. $1.399 \AA$ ) compared to those in 2 (1.438 $\AA$ ) and 5 (av. $1.440 \AA$ ) agree with this description.

The $\mathrm{P}-\mathrm{N}$ and $\mathrm{P}-\mathrm{C}$ bond lengths within the six-membered $\mathrm{CP}_{2} \mathrm{~N}_{2} \mathrm{Zn}$ metallacycles of $\mathbf{1}-\mathbf{5}$ are comparable to those reported for $\mathrm{L}^{2}{ }_{2} \mathrm{Zn}_{2}$ (P-N 1.615(1), 1.615(1); C-P 1.725(1), 1.732(1) Å), $C p^{\star} Z n-Z n L^{3}$ (P-N 1.6277(11), 1.6266(11), C-P 1.7018(13), 1.7163(13) $\AA$ ) and $L^{1} \mathrm{ZnMe}(\mathrm{P}-\mathrm{N} 1.585(3), 1.600(3)$, C-P 1.728(4), 1.739(4) $\AA$ ) as well as other heteroleptic bis(phosphinimino)methanide zinc complexes LZnR. The same is true for the endocyclic P-C-P, N-P-C and N-Zn-N bond angles of 1 - 5 (table 1), which also fall within the broad range reported for these type of complexes. ${ }^{[17]}$

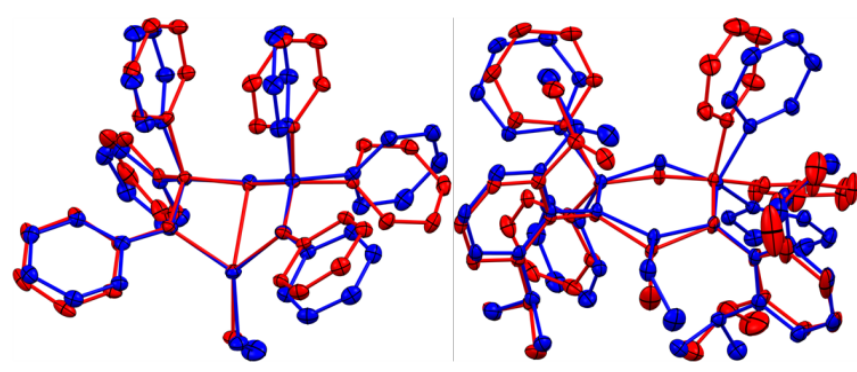

Fig. 3 Overlying structures of complexes containing the same bis(iminophosphorane) substituents (left hand side: $\mathbf{1}$ and $\mathbf{4}$; right hand side: $\mathbf{2}$ and 5), Zn-Me complexes displayed in red, Zn-Et in blue.

The structures of the analogously substituted complexes $\mathbf{1}$ and $\mathbf{4}$ as well as $\mathbf{2}$ and $\mathbf{5}$ are very similar as shown in figure 3 , which 
displays two overlays of the structures. The exchange of a Me by an Et substituent at the $\mathrm{Zn}$ atoms does not lead to any substantial structural changes. The influence of the substituent at the nitrogen atoms on the conformation is far more pronounced. The Cambridge Structural Database (CSD) ${ }^{[18]}$ reveals 212 structures with $\mathrm{C} / \mathrm{SiN}-\mathrm{Ph}_{2} \mathrm{P}-\mathrm{CH}-\mathrm{Ph}_{2} \mathrm{P}-\mathrm{NC} / \mathrm{Si}$ type ligands chelating a metal atom via the $\mathrm{N}$ atoms. Depending on the steric demand of the substituent group bound to the $\mathrm{N}$ atoms the conformation of the six-membered $\mathrm{CP}_{2} \mathrm{~N}_{2} \mathrm{M}$ metallacycle and the torsion about the P/P vector varies. Phenyl and $p$-tolyl groups are almost ecliptic ( $\left.\mathrm{N}-\mathrm{P} \cdots \mathrm{P}-\mathrm{N}<10^{\circ}\right)$, while an increased steric demand leads to larger torsions ( $i-\operatorname{Pr}$ and $\left.t-B u<20^{\circ}\right)$. Metallacycles containing $\mathrm{Me}_{3} \mathrm{Si}$ and mesityl groups bound to the $\mathrm{N}$ atoms can already be considered staggered ( $\mathrm{N}-\mathrm{P} \cdots \mathrm{P}-\mathrm{N}<40^{\circ}$ ), even though $\mathrm{Me}_{3} \mathrm{Si}$-substituted complexes exhibit a quite wide range of conformations, and adamantyl groups lead to nearly perfect staggering $\left(\mathrm{N}-\mathrm{P} \cdots \mathrm{P}-\mathrm{N}>50^{\circ}\right)$. Any outliers can be explained by either intramolecular interactions or dimerization. Since in all cases the backbone carbon atom and the metal atom deviate to the same side from the best plane of the heterocycle, the preferred conformation is of a boat-type which, however, depending on the steric demand of the $\mathrm{N}$ substituents is distorted toward a twisted conformation.

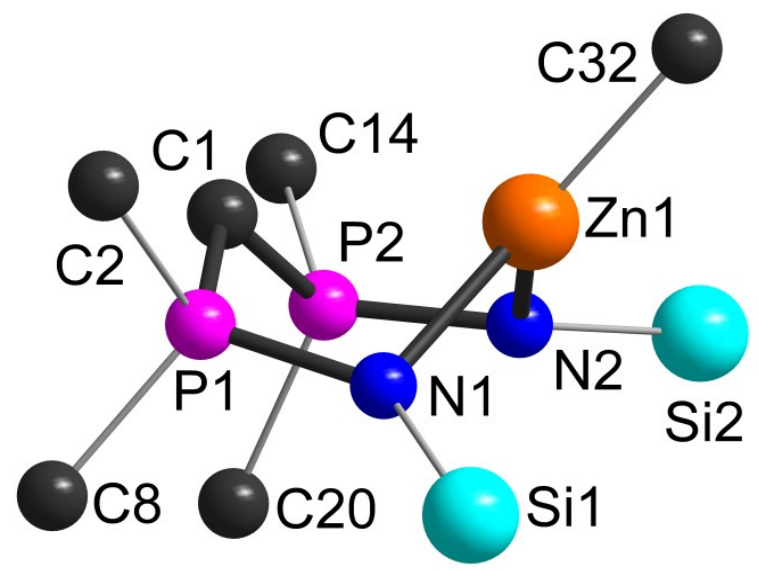

Fig. 4 Boat-type conformation exemplarily shown for 3 ; $\mathrm{H}$ atoms are omitted for clarity. Substituents are reduced to their ipso-atoms for clarity.

Occasionally, trans-annular interactions connecting "bow" and "stern" of the boat have been discussed in these type of metal complexes, in particular for those containing lanthanides and actinide metals. ${ }^{[3]}$ In addition, short trans-annular metal-carbon bonds were also reported for the corresponding alkaline earth metal complexes such as $\left[\left\{\mathrm{HC}\left(\mathrm{PPh}_{2} \mathrm{NSiMe}_{3}\right)_{2}\right\} \mathrm{Ml}(\text { thf })_{2}\right](\mathrm{M}=\mathrm{Ca}$, Sr, Ba; Ca-C1 2.735(6), Sr-C1 2.958(3), Ba-C1 3.127(3) Å), ${ }^{[19]}$ $\left[\left\{\mathrm{HC}\left(\mathrm{PPh}_{2} \mathrm{NMes}\right)_{2}\right\} \mathrm{M}\left\{\mathrm{N}\left(\mathrm{SiMe}_{3}\right)_{2}\right\}\right.$ thf] $(\mathrm{M}=\mathrm{Ca}, \mathrm{Sr} ; \mathrm{Ca}-\mathrm{C} 12.713(7)$,

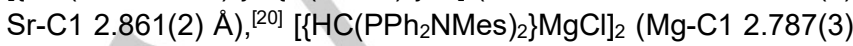
$\AA),{ }^{[21]}\left[\left\{\mathrm{HC}\left(\mathrm{PPh}_{2} \mathrm{NSiMe}_{3}\right)_{2}\right\} \mathrm{MgCl}\right]_{2}(\mathrm{Mg}(1)-\mathrm{C}(31) 2.460(8) \AA)$ and $\left[\left\{\mathrm{HC}\left(\mathrm{PPh}_{2} \mathrm{NSiMe}_{3}\right)_{2}\right\} \mathrm{Mgl}(\right.$ thf $\left.)\right] \quad(\mathrm{Mg}(1)-\mathrm{C}(1) \quad 2.573(6) \quad \AA),{ }^{[22]}$ respectively. In addition, Cavell et al. reported on a short $\mathrm{Zn}-\mathrm{C}$ trans-annular contact in $\left[\left\{\mathrm{HC}\left(\mathrm{PPh}_{2} \mathrm{NSiMe}_{3}\right)_{2}\right\} \mathrm{ZnMe}\right.$ (Zn1-C1 $2.527(4) \AA),{ }^{[6 a]}$ which agrees very well with the values observed in 1,3 , and 4 , whereas the complexes 2 and 5 , which contain the sterically most demanding Dipp substituent $\left(L^{3}\right)$, show significantly longer Zn1-C1 distances (3.392(6) 2, 3.3869(19) 5). In addition to the trans-annular interactions in these type of complexes, 58 of the structures listed in the Cambridge database have phenyl rings close to parallel (interplanar angle less than $15^{\circ}$ ) and inter-centroid distances of less than $3.7 \AA$, suggesting that $\pi \cdots \pi$ interactions might influence the conformation in a way similar to the "offset face-to-face" interaction as-described by Lewis et al. for the PPN-cation. ${ }^{[23]}$

\section{Conclusions}

Heteroleptic bis(phosphinimino)methanide complexes of the general type $L Z n M e\left(L^{2} 1, L^{3} 2\right)$ and $L Z n E t\left(L^{1} 3, L^{2} 4, L^{3} 5\right)$ were obtained from reactions of $\mathrm{H}_{2} \mathrm{C}\left(\mathrm{PPh}_{2} \mathrm{NR}\right)_{2}$ with $\mathrm{ZnMe}_{2}$ and $\mathrm{ZnEt}_{2}$, respectively. In contrast, any attempts toward double deprotonation of $\mathrm{H}_{2} \mathrm{C}\left(\mathrm{PPh}_{2} \mathrm{NR}\right)_{2}$ by equimolar reactions at elevated temperatures and formation of mononuclear complexes ( $\left[\mathrm{C}\left(\mathrm{PPh}_{2} \mathrm{~N}-2,6-i-\mathrm{Pr}_{2}-\mathrm{C}_{6} \mathrm{H}_{3}\right)_{2}\right] \mathrm{Zn}$ (carbene-like complexes) or by using two equivalents of the zinc dialkyl and formation of dinuclear bis(phosphinimino)methanediide complexes of the type $\left[\mathrm{C}\left(\mathrm{PPh}_{2} \mathrm{~N}-2,6-i-\mathrm{Pr}_{2}-\mathrm{C}_{6} \mathrm{H}_{3}\right)_{2}\right](\mathrm{ZnR})_{2}$ failed.

\section{Experimental Section}

General Procedures. All manipulations were performed in a Glovebox (MBraun) under an Ar atmosphere or with standard Schlenk techniques. Solvents were carefully dried over $\mathrm{Na} / \mathrm{K}$ and degassed prior to use. Bis(iminophosphorane)methanes $\mathrm{H}_{2} \mathrm{C}\left(\mathrm{PPh}_{2} \mathrm{NR}\right)_{2}$ were prepared according to literature procedures, ${ }^{[24]}$ while $\mathrm{ZnMe}_{2}$ and $\mathrm{ZnEt}_{2}$ were commercially available. NMR spectra were recorded on a Bruker Avance 300 spectrometer at $25{ }^{\circ} \mathrm{C}$ at $300 \mathrm{MHz}\left({ }^{1} \mathrm{H}\right), 75 \mathrm{MHz}\left({ }^{13} \mathrm{C}\right)$ and $121 \mathrm{MHz}$ $\left({ }^{31} \mathrm{P}\right)$, respectively, and referenced to internal $\mathrm{C}_{6} \mathrm{D}_{5} \mathrm{H}\left({ }^{1} \mathrm{H}: \delta=7.154 ;{ }^{13} \mathrm{C}\right.$ : $\delta=128.0)$. IR spectra were recorded on a Bruker ALPHA-T FT-IR spectrometer equipped with a single reflection ATR sampling module. Melting points were measured in sealed capillaries and were not corrected. Elemental analyses were performed at the Elementaranalyse Labor of the University of Duisburg-Essen.

General synthesis of $\left[\mathrm{HC}\left(\mathrm{PPh}_{\mathbf{2}} \mathbf{N R}\right)_{2}\right] \mathrm{ZnMe} . \mathrm{ZnMe}_{2}(1.2 \mathrm{M}$ in toluene, $0.42 \mathrm{~mL}, 0.5 \mathrm{mmol}$ ) was slowly added to a solution of $0.5 \mathrm{mmol}$ $\mathrm{H}_{2} \mathrm{C}\left(\mathrm{PPh}_{2} \mathrm{NR}\right)_{2}\left(\mathrm{R}=\mathrm{Ph} 0.28 \mathrm{~g}, 2,6-i-\mathrm{Pr}_{2}-\mathrm{C}_{6} \mathrm{H}_{3} 0.35 \mathrm{~g}\right)$ in $15 \mathrm{~mL}$ of toluene at ambient temperature, immediately resulting in a smooth gas evolution, and the reaction mixture was stirred for additional $2 \mathrm{~h}$ at room temperature. The solution was then concentrated to $5 \mathrm{~mL}$ and colorless plates, which were suitable for a single crystal X-ray diffraction study, were obtained after storage at room temperature for $12 \mathrm{~h}$.

[HC(PPh $\left.{ }_{2} \mathbf{N P h}\right)_{2}$ ]ZnMe 1. Yield: $0.25 \mathrm{~g}(81 \%) . \mathrm{Mp} .: 236{ }^{\circ} \mathrm{C}$ (dec.). Anal. found (calcd) for $\mathrm{C}_{38} \mathrm{H}_{34} \mathrm{~N}_{2} \mathrm{P}_{2} \mathrm{Zn}(645.98 \mathrm{~g} / \mathrm{mol})$ : C, 70.65 (70.70); H, 5.26 (5.27); N, 4.33 (4.34). ${ }^{1} \mathrm{H}$ NMR (300 MHz, $\left.\mathrm{C}_{6} \mathrm{D}_{6}, 25^{\circ} \mathrm{C}\right): \delta=0.41$ (s, $3 \mathrm{H}$, $\mathrm{ZnMe}$ ), 1.82 (t, 1H, $\left.{ }^{2} \mathrm{JPH}_{\mathrm{P}}=4.7 \mathrm{~Hz}, \mathrm{PCHP}\right), 6.69-7.06(\mathrm{~m}, 22 \mathrm{H}, \mathrm{Ph}), 7.58-$ $7.65\left(\mathrm{~m}, 8 \mathrm{H}, \mathrm{o}-\mathrm{Ph}{ }_{2} \mathrm{P}\right) .{ }^{13} \mathrm{C} \mathrm{NMR}\left(75 \mathrm{MHz}, \mathrm{C}_{6} \mathrm{D}_{6}, 25^{\circ} \mathrm{C}\right): \delta=-13.5(\mathrm{ZnMe})$, 23.8 (PCHP), $119.3\left(\mathrm{~s}, p-P h_{N}\right), 121.8\left(\mathrm{dt},{ }^{4} J_{\mathrm{CP}}=4.3 \mathrm{~Hz}, p-P h_{p}\right), 127.9(\mathrm{~s}$, $\left.m-P h_{P}\right), 128.5\left(\mathrm{~s}, m-P h_{N}\right), 129.3\left(\mathrm{~m}, o-P h_{P}\right), 130.9\left(\mathrm{~m}, o-P h_{N}\right) 132.4$ 
(quint, $\left.{ }^{1} \mathrm{~J}_{\mathrm{CP}}=5.1 \mathrm{~Hz}, i-P h_{P}\right), 149.8\left(\mathrm{t},{ }^{2} \mathrm{~J}_{\mathrm{CP}}=3.0 \mathrm{~Hz}, i-P h_{N}\right) .{ }^{31} \mathrm{P} \mathrm{NMR}(300$ $\left.\mathrm{MHz}, \mathrm{C}_{6} \mathrm{D}_{6}, 25^{\circ} \mathrm{C}\right): \delta=23.8$. ATR-IR: $\mathrm{v}=3049,2927,2893,2823,1589$, $1480,1434,1289,1266,1174,1106,1075,1031,997,955,878,805$, $788,749,737,687,625,606,544,519,492,465,403 \mathrm{~cm}^{-1}$.

[HC( $\left.\mathrm{PPh}_{2} \mathrm{~N}-2,6-\mathbf{6}-\mathrm{Pr}_{2}-\mathrm{C}_{6} \mathrm{H}_{3}\right)_{2}$ ] ZnMe 2. Yield: 0.29 g (78 \%). $\mathrm{Mp}$. $297{ }^{\circ} \mathrm{C}$ (dec.). Anal. found (calcd) for $\mathrm{C}_{50} \mathrm{H}_{58} \mathrm{~N}_{2} \mathrm{P}_{2} \mathrm{Zn}(814.29 \mathrm{~g} / \mathrm{mol})$ : C, 73.80 (73.74); H, 7.24 (7.18); N; 3.41 (3.44). ${ }^{1} \mathrm{H}$ NMR $\left(300 \mathrm{MHz}, \mathrm{C}_{6} \mathrm{D}_{6}\right.$, $\left.25^{\circ} \mathrm{C}\right): \delta=-0.59(\mathrm{~s}, 3 \mathrm{H}, \mathrm{ZnMe}), 0.66\left(\mathrm{~d}, 12 \mathrm{H},{ }^{3} \mathrm{JHH}_{\mathrm{HH}}=6.9 \mathrm{~Hz}, \mathrm{CH}\left(\mathrm{CH}_{3}\right)_{2}\right)$, $1.41\left(\mathrm{~d}, 12 \mathrm{H},{ }^{3} \mathrm{~J}_{\mathrm{HH}}=6.9 \mathrm{~Hz}, \mathrm{CH}\left(\mathrm{CH}_{3}\right)_{2}\right), 1.65$ (s, $1 \mathrm{H}, \mathrm{PCHP}$ ), 3.93 (sept $\left.4 \mathrm{H},{ }^{3} \mathrm{~J}_{\mathrm{HH}}=6.8 \mathrm{~Hz}, \mathrm{CH}\left(\mathrm{CH}_{3}\right)_{2}\right), 6.98\left(\mathrm{~m}, 12 \mathrm{H}, \mathrm{PhH}_{\mathrm{H}}, 7.08\left(\mathrm{~m}, 6 \mathrm{H}, \mathrm{C}_{6} \mathrm{H}_{3} \mathrm{i}_{-}\right.\right.$ $\left.\mathrm{Pr}_{2}-2,6\right), 7.56-7.62\left(\mathrm{~m}, 8 \mathrm{H}, \mathrm{PhH}_{H}\right) .{ }^{13} \mathrm{C}$ NMR $\left(75 \mathrm{MHz}, \mathrm{C}_{6} \mathrm{D}_{6}, 25^{\circ} \mathrm{C}\right): \delta=-$

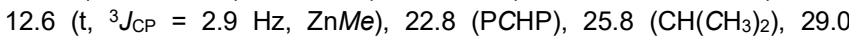
$\left(\mathrm{CH}\left(\mathrm{CH}_{3}\right)_{2}\right), 124.0\left(\mathrm{~m}, p-P h_{P}\right), 124.5\left(\mathrm{~m}, p-P h_{N}\right), 127.9$ (quint, ${ }^{3} \mathrm{~J}_{\mathrm{CP}}=4.7$ $\left.\mathrm{Hz}, m-P h_{P}\right), 128.3$ (s, $\left.m-P h_{N}\right) 130.5$ (m, o-PhP), 132.9 (quint, ${ }^{3} \mathrm{JCP}_{\mathrm{CP}}=2.8$ $\left.\mathrm{Hz}, o-P h_{N}\right), 135.6\left(\mathrm{~d},{ }^{1} J_{\mathrm{CP}}=2.8, i-P h_{P}\right), 136.9\left(\mathrm{~d},{ }^{1} \mathrm{~J}_{\mathrm{CP}}=2.8, i-P h_{P}\right), 143.5$ $\left(\mathrm{t},{ }^{2} J_{\mathrm{CP}}=4.6 \mathrm{~Hz}, i-P h_{N}\right), 146.4\left(\mathrm{t},{ }^{2} J_{\mathrm{CP}}=2.6 \mathrm{~Hz}, i-P h_{N}\right) .{ }^{31} \mathrm{P} \mathrm{NMR}(300$ $\left.\mathrm{MHz}, \mathrm{C}_{6} \mathrm{D}_{6}, 25^{\circ} \mathrm{C}\right): \delta=29.4$. ATR-IR: $v=3049,3014,2956,2864,1587$ 1459, 1431, 1380, 1341, 1315, 1243, 1186, 1156, 1098, 1042, 1009, 987 $963,820,803,790,733,690,598,533,514,494,383 \mathrm{~cm}^{-1}$

General synthesis of $\left[\mathrm{HC}\left(\mathrm{PPh}_{2} \mathrm{NR}\right)_{2}\right] \mathrm{ZnEt}$. ZnEt 2 (1 M in hexane, 1.00 $\mathrm{mL}, 1.0 \mathrm{mmol}$ ) was added via syringe to a solution of $0.5 \mathrm{mmol}$ $\mathrm{H}_{2} \mathrm{C}\left(\mathrm{PPh}_{2} \mathrm{NR}\right)_{2}\left(\mathrm{R}=\mathrm{SiMe}_{3} 0.27 \mathrm{~g}, \mathrm{Ph} 0.28 \mathrm{~g}, 2,6-i-\mathrm{Pr}_{2}-\mathrm{C}_{6} \mathrm{H}_{3} 0.35 \mathrm{~g}\right)$ in 15 $\mathrm{mL}$ of toluene at ambient temperature. After the gas evolution has stopped, the resulting solution was stirred for $12 \mathrm{~h}$. The solvent was then removed in vacuum and the crude product was washed with cold pentane. Re-crystallization of the remaining colorless solid from a concentrated solutions of $\mathbf{3}-\mathbf{5}$ in $2 \mathrm{~mL}$ of toluene or thf at $0{ }^{\circ} \mathrm{C}$ yielded colorless crystals of $\mathbf{3}-\mathbf{5}$ within $24 \mathrm{~h}$.

[HC(PPh $\left.\mathrm{NSiMe}_{3}\right)_{2}$ ]ZnEt 3. Yield: $0.25 \mathrm{~g}(78 \%)$. Mp.: $>220^{\circ} \mathrm{C}$ (dec.) Anal. found (calcd) for $\mathrm{C}_{33} \mathrm{H}_{44} \mathrm{~N}_{2} \mathrm{P}_{2} \mathrm{Si}_{2} \mathrm{Zn}(652.23 \mathrm{~g} / \mathrm{mol}): \mathrm{C}, 60.65(60.77)$; $\mathrm{H}, 6.69$ (6.80); N, 4.23 (4.29). ${ }^{1} \mathrm{H}$ NMR $\left(300 \mathrm{MHz}, \mathrm{C}_{6} \mathrm{D}_{6}, 25^{\circ} \mathrm{C}\right): \delta=0.12$ (s, $18 \mathrm{H}, \mathrm{SiMe}_{3}$ ), 0.95 (quart, $2 \mathrm{H},{ }^{3} \mathrm{JHH}_{\mathrm{HH}}=8.1 \mathrm{~Hz}, \mathrm{ZnCH}_{2} \mathrm{CH}_{3}$ ), $1.84(\mathrm{t}, 3 \mathrm{H}$, $\left.{ }^{3} \mathrm{~J}_{\mathrm{HH}}=8.0 \mathrm{~Hz}, \mathrm{ZnCH}_{2} \mathrm{CH}_{3}\right), 1.93\left(\mathrm{t}, 1 \mathrm{H},{ }^{2} \mathrm{~J}_{\mathrm{PH}}=4.0 \mathrm{~Hz}, \mathrm{PCHP}\right), 6.69-7.07$ $(\mathrm{m}, 12 \mathrm{H}, P h), 7.59-7.66\left(\mathrm{~m}, 8 \mathrm{H}, \mathrm{o}-P h_{2} \mathrm{P}\right) .{ }^{13} \mathrm{C}$ NMR $\left(75 \mathrm{MHz}, \mathrm{C}_{6} \mathrm{D}_{6}\right.$ $\left.25{ }^{\circ} \mathrm{C}\right): \delta=3.7\left(\mathrm{t},{ }^{3} \mathrm{~J} \mathrm{CP}=1.7 \mathrm{~Hz}, \mathrm{SiMe}\right), 4.0\left(\mathrm{ZnCH}_{2} \mathrm{CH}_{3}\right), 13.8$ $\left(\mathrm{ZnCH}_{2} \mathrm{CH}_{3}\right.$ ), 28.2 (PCHP), 128.1 (quint, ${ }^{2} \mathrm{~J}_{\mathrm{CP}}=6.0 \mathrm{~Hz}, \mathrm{o}-\mathrm{Ph}$ ), 130.4 (s $p$-PhP), 131.8 (quint, $\left.{ }^{3} \mathrm{~J}_{\mathrm{CP}}=5.2 \mathrm{~Hz}, m-P h_{P}\right) 137.6\left(\mathrm{~d},{ }^{1} \mathrm{~J}_{\mathrm{CP}}=3.9 \mathrm{hz}, i-P h_{P}\right)$. ${ }^{31} \mathrm{P}$ NMR $\left(300 \mathrm{MHz}, \mathrm{C}_{6} \mathrm{D}_{6}, 25{ }^{\circ} \mathrm{C}\right): \delta=26.0$. ATR-IR: $v=3074,3055$ $3008,2948,2888,2846,1590,1482,1435,1259,1242,1151,1126$, $1105,1026,999,929,827,800,764,709,691,655,614,589,544,511$, $497,478,449,418,395,385 \mathrm{~cm}^{-1}$.

[HC(PPh $\left.{ }_{2} \mathrm{NPh}\right)_{2}$ ]ZnEt 4. Yield: $0.28 \mathrm{~g}(85 \%)$. Mp.: $>220^{\circ} \mathrm{C}$ (dec.). Anal. found (calcd) for $\mathrm{C}_{38} \mathrm{H}_{34} \mathrm{~N}_{2} \mathrm{P}_{2} \mathrm{Zn}(660.07 \mathrm{~g} / \mathrm{mol})$ : C, 70.85 (70.96); $\mathrm{H}, 5.46$ (5.50); N, 4.36 (4.42). ${ }^{1} \mathrm{H}$ NMR $\left(300 \mathrm{MHz}, \mathrm{C}_{6} \mathrm{D}_{6}, 25^{\circ} \mathrm{C}\right): \delta=1.28$ (quart $\left.2 \mathrm{H},{ }^{3} \mathrm{JHH}_{\mathrm{HH}}=8.1 \mathrm{~Hz}, \mathrm{ZnCH}_{2} \mathrm{CH}_{3}\right), 1.83\left(\mathrm{t}, 1 \mathrm{H},{ }^{2} \mathrm{JPH}_{\mathrm{PH}}=4.8 \mathrm{~Hz}, \mathrm{PCHP}\right), 1.86(\mathrm{t}$, $\left.3 \mathrm{H},{ }^{3} \mathrm{~J}_{\mathrm{HH}}=8.1 \mathrm{~Hz}, \mathrm{ZnCH}_{2} \mathrm{CH}_{3}\right), 6.69-7.06(\mathrm{~m}, 22 \mathrm{H}, \mathrm{Ph}), 7.58-7.65(\mathrm{~m}, 8 \mathrm{H}$ o-Ph $2 \mathrm{P}) \cdot{ }^{13} \mathrm{C}$ NMR $\left(75 \mathrm{MHz}, \mathrm{C}_{6} \mathrm{D}_{6}, 25{ }^{\circ} \mathrm{C}\right): \delta=1.2\left(\mathrm{ZnCH}_{2} \mathrm{CH}_{3}\right), 14.0$ $\left(\mathrm{ZnCH}_{2} \mathrm{CH}_{3}\right), 23.8(\mathrm{PCHP}), 119.3\left(\mathrm{~s}, p-P h_{N}\right), 121.7\left(\mathrm{dt},{ }^{4} \mathrm{~J} \mathrm{CP}=4.0 \mathrm{~Hz}, p\right.$ $\left.P h_{P}\right), 128.4$ (quint, $\left.{ }^{3} \mathrm{~J}_{\mathrm{CP}}=4.0 \mathrm{~Hz}, m-P h_{P}\right), 128.7\left(\mathrm{~s}, m-P h_{N}\right), 129.0(\mathrm{~s}, o-$ $\left.P h_{P}\right), 130.9\left(\mathrm{~s}, o-P h_{N}\right) 132.3\left(\mathrm{~m}, i-P h_{P}\right), 149.9\left(\mathrm{t},{ }^{1} \mathrm{JCP}_{\mathrm{CP}}=2.7 \mathrm{~Hz}, i-P h_{N}\right) .{ }^{31} \mathrm{P}$ NMR $\left(300 \mathrm{MHz}, \mathrm{C}_{6} \mathrm{D}_{6}, 25^{\circ} \mathrm{C}\right): \delta=23.6$. ATR-IR: $\mathrm{v}=3074,3051,2989$, 2922, 2884, 2848, 1598, 1481, 1434, 1326, 1393, 1266, 1174, 1105, $1075,1032,998,948,877,802,781,736,687,628,606,543,521,492$, $464,403 \mathrm{~cm}^{-1}$.

[HC( $\left.\mathrm{PPh}_{2} \mathrm{~N}-\mathbf{2}, \mathbf{6}-\mathbf{i}-\mathrm{Pr}_{2}-\mathrm{C}_{6} \mathrm{H}_{3}\right)_{2}$ ]ZnEt 5. Yield: $0.35 \mathrm{~g}(84 \%) . \mathrm{Mp} .:>220^{\circ} \mathrm{C}$ (dec.). Anal. found (calcd) for $\mathrm{C}_{51} \mathrm{H}_{60} \mathrm{~N}_{2} \mathrm{P}_{2} \mathrm{Zn}(828.39 \mathrm{~g} / \mathrm{mol})$ : C, 73.88 (73.94); $\mathrm{H}, 7.26$ (7.30); N; 3.41 (3.38). ${ }^{1} \mathrm{H}$ NMR (300 MHz, $\left.\mathrm{C}_{6} \mathrm{D}_{6}, 25^{\circ} \mathrm{C}\right)$ : $\delta=0.31$ (quart, $\left.2 \mathrm{H},{ }^{3} \mathrm{JHH}_{\mathrm{HH}}=8.1, \mathrm{ZnCH}_{2} \mathrm{CH}_{3}\right), 0.65\left(\mathrm{~d}, 12 \mathrm{H},{ }^{3} \mathrm{JHH}_{\mathrm{HH}}=6.7 \mathrm{~Hz}\right.$, $\left.\mathrm{CH}\left(\mathrm{CH}_{3}\right)_{2}\right), 0.93\left(\mathrm{t}, 3 \mathrm{H},{ }^{3} \mathrm{~J}_{\mathrm{HH}}=8.0 \mathrm{~Hz}, \mathrm{ZnCH}_{2} \mathrm{CH}_{3}\right), 1.46\left(\mathrm{~d}, 12 \mathrm{H},{ }^{3} \mathrm{~J}_{\mathrm{HH}}=\right.$
6.7, $\mathrm{CH}\left(\mathrm{CH}_{3}\right)_{2}$ ), 1.64 (s, 1H, PCHP), 3.93 (sept, 4H, ${ }^{3} \mathrm{~J}_{\mathrm{HH}}=6.8 \mathrm{~Hz}$, $\left.\mathrm{CH}\left(\mathrm{CH}_{3}\right)_{2}\right), 6.92-7.10\left(\mathrm{~m}, 18 \mathrm{H}, \mathrm{Ph}_{H}, \mathrm{C}_{6} \mathrm{H}_{3} i-\mathrm{Pr}_{2}-2,6\right), 7.56-7.63(\mathrm{~m}, 8 \mathrm{H}$, $\left.P h_{H}\right) .{ }^{13} \mathrm{C}$ NMR $\left(75 \mathrm{MHz}, \mathrm{C}_{6} \mathrm{D}_{6}, 25^{\circ} \mathrm{C}\right): \delta=1.8\left(\mathrm{t},{ }^{3} \mathrm{~J}_{\mathrm{CP}}=3.0 \mathrm{~Hz}\right.$,

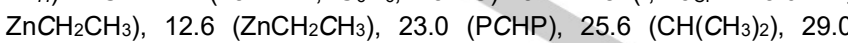
$\left(\mathrm{CH}\left(\mathrm{CH}_{3}\right)_{2}\right), 124.0(\mathrm{~m}, p-P h P), 124.5(\mathrm{~m}, p-P h N), 127.7$ (quint, ${ }^{3} \mathrm{~J}_{\mathrm{CP}}=6.0$ $\left.\mathrm{Hz}, m-P h_{P}\right), 128.4\left(\mathrm{~s}, m-P h_{N}\right), 130.4\left(\mathrm{~s}, o-P h_{P}\right), 132.9$ (quint, ${ }^{3} \mathrm{JCP}=4.6$ $\left.\mathrm{Hz}, o-P h_{N}\right), 135.7\left(\mathrm{~d},{ }^{1} J_{\mathrm{CP}}=2.8 \mathrm{~Hz}, i-P h_{P}\right), 136.9\left(\mathrm{~d},{ }^{1} \mathrm{~J}_{\mathrm{CP}}=2.8 \mathrm{~Hz}, i-P h_{P}\right)$, $143.7\left(\mathrm{t},{ }^{2} \mathrm{JCP}_{\mathrm{CP}}=4.6 \mathrm{~Hz}, i-P h_{N}\right), 146.2\left(\mathrm{t},{ }^{2} \mathrm{~J}_{\mathrm{CP}}=2.8 \mathrm{~Hz}, i-P h_{N}\right) .{ }^{31} \mathrm{P} \mathrm{NMR}$ $\left(300 \mathrm{MHz}, \mathrm{C}_{6} \mathrm{D}_{6}, 25^{\circ} \mathrm{C}\right): \delta=28.9$. ATR-IR: $v=3077,3051,3024,2961$, $2945,2882,2850,1588,1481,1455,1431,1318,1247,1186,1099,987$, $931,831,795,742,708,691,599,532,515,500,451,406,378 \mathrm{~cm}^{-1}$.

Single crystal X-ray diffraction. Crystals of 1 - 5 were mounted on nylon loops in inert oil. Crystallographic data of $\mathbf{1}-\mathbf{5}$ are summarized in Table S1. Figures 1 and 2 show the solid state structures of 1 and 3 while the structures of $\mathbf{2 , 4}$ and $\mathbf{5}$ are given in the electronic supplement. selected bond lengths and angles are summarized in table 1. Data were collected on a Bruker AXS D8 Kappa diffractometer with APEX2 detector (mono-chromated $\mathrm{Mo}_{\alpha}$ radiation, $\lambda=0.71073 \AA$ ) at $100(1) \mathrm{K}$. The structures were solved by Direct Methods (SHELXS-97) ${ }^{[25]}$ and refined anisotropically by full-matrix least-squares on $F^{2}$ (SHELXL-97). ${ }^{[26]}$ Absorption corrections was performed semi-empirically from equivalent reflections on basis of multi-scans (Bruker AXS APEX2, TWINABS 2). All non-hydrogen atoms were refined anisotropically and hydrogen atoms were refined using a riding model or rigid methyl groups. In $\mathbf{3}$ and $\mathbf{4} \mathrm{H} 1$ was refined freely to improve the fit on the residual electron density. 2 was non-merohedrally twinned and refined against HKLF5 data. The crystallographic data of $\mathbf{1}$ - $\mathbf{5}$ (excluding structure factors) have been deposited with the Cambridge Crystallographic Data Centre as supplementary publication no. CCDC-1482571 (1), CCDC-1482572 (2), CCDC-1482573 (3), CCDC-1482574 (4) and CCDC-1482575 (5). Copies of the data can be obtained free of charge on application to CCDC, 12 Union Road, Cambridge, CB21EZ (fax: (+44) 1223/336033; e-mail: deposit@ccdc.cam-ak.uk).

\section{Acknowledgements}

S. Schulz thanks the University of Duisburg-Essen for financial support.

Keywords: zinc $\cdot$ bis(phosphinimino)methanide $\cdot$ single crystal structure

[1] a) H. Staudinger, J. Meyer, Helv. Chim. Acta 1919, 635-646; b) Y. G Gololobov, I. N. Zhmurova and L. F. Kasukhin, Tetrahedron 1981, 37 437-472; c) Y. G. Gololobov, L. F. Kasukhin, Tetrahedron 1992, 48 1353-1406.

[2] a) A. V. Kirsanov, Izv. Akad. Nauk SSSR 1950, 426-437; b) M. Demange, L. Boubekeur, A. Auffrant, N. Mézailles, L. Ricard, X. Le Goff, P. Le Floch, New J. Chem. 2006, 30, 1745-1754

[3] For review articles see: a) T. K. Panda, P. W. Roesky, Chem. Soc. Rev. 2009, 38, 2782-2804; b) S. T. Liddle, D. P. Mills, A. J. Wooles, Chem. Soc. Rev. 2011, 40, 2164-2176; c) S. Harder, Coord. Chem. Rev. 2011 255, 1252-1267; d) V. H. Gessner, J. Becker, K.-S. Feichtner, Eur. J. Inorg. Chem. 2015, 1841-1859

[4] a) M. S. Hill, P. B. Hitchcock, Dalton Trans. 2002, 4694-4702; b) M. T. Gamer, M. Rastatter, P. W. Roesky, A. Steffens, M. Glanz, Chem.-Eur J. 2005, 11, 3165-3172; c) T. K. Panda, A. Zulys, M. T. Gainer, P. W Roesky, Organometallics 2005, 24, 2197-2202; d) T. K. Panda, M. T. Gamer, P. W. Roesky, Inorg. Chem. 2006, 45, 910-916; e) J. Jenter, P. W. Roesky, N. Ajellal, S. M. Guillaume, N. Susperregui, L. Maron, 
Chem. Eur. J. 2010, 16, 4629-4638; f) S. M. Guillaume, P. Brignou, N. Susperregui, L. Maron, M. Kuzdrowska, J. Kratsch, P. W. Roesky Polym. Chem. 2012, 3, 429-435; g) S. Marks, M. Kuzdrowska, P. W. Roesky, L. Annunziata, S. M. Guillaume, L. Maron, ChemPlusChem 2012, 77, 350-353; h) S. M. Guillaume, Eur. Polym. J. 2013, 49, 768779; i) A. T. Normand, A. Massard, P. Richard, C. Canovas, C. Balan, M. Picquet, A. Auffrant, P. Le Gendre, Dalton Trans. 2014, 43, 1509815110.

[5] S. Marks, T. K. Panda, P. W. Roesky, Dalton Trans. 2010, 39, 72307235 .

[6] a) A. Kasani, R. McDonald, R. G. Cavell, Organometallics 1999, 18, 3775-3777; b) M.S.Hill, P.B.Hitchcock, Dalton Trans. 2002, 4694-4702 c) S. Marks, R. Köppe, T. K. Panda, P. W. Roesky, Chem.-Eur. J. 2010 16, 7096-7100; d) X.-X. Zheng, C. Zhang, Z.-X. Wang, J. Organomet. Chem. 2015, 783, 105-115.

[7] T. Bollwein, M. Westerhausen, A. Pfitzner, Z. Naturforsch. B 2003, 58, 493-495

[8] See for instance: a) A. Buchard, R. H. Platel, A. Auffrant, X. F. Le Goff, P. Le Floch, C. K. Williams, Organometallics 2010, 29, 2892-2900; b) H. Xie, Z. Mou, B. Liu, P. Li, W. Rong, S. Li, D. Cui, Organometallics 2014, 33, 722-730

[9] a) M. Münch, U. Flörke, M. Bolte, S. Schulz, D. Gudat, Angew. Chem. 2008, 120, 1535-1537; Angew. Chem. Int. Ed. 2008, 47, 1512-1516; b) T. Eisenmann, J. Khanderi, S. Schulz, U. Flörke, Z. Anorg. Allg. Chem. 2008, 634, 507-513; c) S. Schmidt, S. Gondzik, S. Schulz, D. Bläser, R. Boese, Organometallics 2009, 28, 4371-4376; d) S. Schmidt, S. Schulz, M. Bolte, Z. Anorg. Allg. Chem. 2009, 635, 2210-2213; e) S. Schulz, T. Eisenmann, D. Bläser, R. Boese, Z. Anorg. Allg. Chem. 2009, 635, 9951000 ; f) S. Schmidt, S. Schulz, D. Bläser, R. Boese, M. Bolte Organometallics 2010, 29, 6097-6103; g) B. Gutschank, S. Schulz, D. Bläser, R. Boese, C. Wölper, Organometallics 2010, 29, 6133-6136; h) B. Gutschank, S. Schulz, U. Westphal, D. Bläser, R. Boese, Organometallics 2010, 29, 2093-2097; i) S. Schmidt, B. Gutschank, S Schulz, D. Bläser, R. Boese, C. Wölper, Eur. J. Inorg. Chem. 2011, 28 4464-4470; j) B. Gutschank, S. Schulz, M. Marcinkowski, G. Jansen, H. Bandmann, D. Bläser, C. Wölper, Angew. Chem. 2012, 124, $11051-$ 11055; Angew. Chem. Int. Ed. 2012, 51, 10893-10897; k) S. Schulz, S. Schmidt, D. Bläser, C. Wölper, Z. Anorg. Allg. Chem. 2012, 638, 17051710 ; I) B. Gutschank, M. Bayram, S. Schulz, D. Bläser, C. Wölper, Eur. J. Inorg. Chem. 2013, 31, 5495-5502; m) S. Schulz, M. Bayram, D. Bläser, C. Wölper, Organometallics 2014, 33, 2080-2087.

[10] a) S. Schulz, T. Eisenmann, D. Schuchmann, M. Bolte, M. Kirchner, R. Boese, J. Spielmann, S. Harder, Z. Naturforsch. 2009, 64b, 1397-1400 b) S. Schulz, D. Schuchmann, U. Westphal, M. Bolte, Organometallics, 2009, 28, 1590-1592, c) S. Schulz, T. Eisenmann, U. Westphal, S. Schmidt, U. Flörke, Z. Anorg. Allg. Chem. 2009, 635, 216-220; d) S.
Schulz, T. Eisenmann, S. Schmidt, D. Bläser, U. Westphal, R. Boese, Chem. Commun. 2010, 46, 7226-7228; e) S. Schulz, J. Spielmann, D Bläser, C. Wölper, Chem. Commun. 2011, 47, 2676-2778; f) G. Bendt, S. Schulz, J. Spielmann, S. Schmidt, D. Bläser, C. Wölper, Eur. J. Inorg Chem. 2012, 23, 3725-3731; g) C. Scheiper, S. Schulz, C. Wölper, D. Bläser, J. Roll, Z. Anorg. Allg. Chem. 2013, 639, 1153-1159; h) C. Scheiper, D. Naglav, D. Bläser, C. Wölper, S. Schulz, Z. Anorg. Allg. Chem. 2015, 641, 871-875; i) S. Gondzik, D. Bläser, C. Wölper, S Schulz, J. Organomet. Chem. 2015, 783, 92-95.

[11] a) S. Schmidt, R. Schäper, S. Schulz, D. Bläser, C. Wölper, Organometallics 2011, 30, 1073-1078; b) S. Schulz, R. Schäper, D. Bläser and C. Wölper, Z. Anorg. Allg. Chem. 2012, 638, 2102-2105; c) S. Schmidt, S. Schulz, D. Bläser, C. Wölper, Main Group Metal Chem. 2012, 35, 35-40.

[12] C. Scheiper, D. Dittrich, C. Wölper, D. Bläser, J. Roll, S. Schulz, Eur. J. Inorg. Chem. 2014, 2230-2240

[13] S. Schulz, S. Gondzik, D. Schuchmann, U. Westphal, L. Dobrzycki, R. Boese, S. Harder, Chem. Commun. 2010, 46, 7757-7759.

[14] L'ZnMe was previously synthesized by Cavell et al.[6a]

[15] M. Bayram, D. Naglav, C. Wölper, S. Schulz, Organometallics, accepted for publication.

[16] Nine heteroleptic bis(phosphinimino)methanide zinc complexes with threefold-coordinated $\mathrm{Zn}$ atom of the type [HC(PPh2NR)2]ZnR' (R' = alkyl, aryl, amide, alkoxide) are reported in the CCDC database.

[17] Eleven heteroleptic $\mathrm{Zn}(\mathrm{I})$ and $\mathrm{Zn}$ (II) complexes containing monoanionic bis(phosphinimino)methanide ligands are reported in the CCDC database. P-C-P: 120.1 - $133.2^{\circ}$, mean value $126.0(1)^{\circ}$; C-P-N: 104.1 $115.2^{\circ}$, mean value $109.7(1)^{\circ} ; \mathbf{N}-\mathbf{Z n}-\mathbf{N}$ : $98.8-114.2^{\circ}$, mean value $105.6(1)^{\circ}$

[18] Cambridge Structural Database, Version 5.37 Feb 2016, see also: F. H. Allen, Acta Cryst., 2002, B58, 380-388.

[19] T. K. Panda, A. Zulys, M. T. Gamer, P. W. Roesky, J. Organomet Chem. 2005, 690, 5078-5089.

[20] M. S. Hill, P. B. Hitchcock, Chem. Commun. 2003, 1758-1759.

[21] S. A. Ahmed, M. S. Hill, P. B. Hitchcock, Organometallics 2006, 25 394-402.

[22] P. Wei, D. W. Stephan, Organometallics 2003, 22, 601-604.

[23] G. R. Lewis, I. Dance, Dalton Trans. 2000, 299-306.

[24] R. Appel, I. Ruppert, Z. Anorg. Allg. Chem. 1974, 406, 131-144

[25] G. M. Sheldrick, Acta Crystallogr. A 1990, 46, 467-473.

[26] G. M. Sheldrick, SHELXL-97, Program for the Refinement of Crystal Structures University of Göttingen, Göttingen (Germany) 1997. See also: G. M. Sheldrick, Acta Crystallogr. A 2008, 64, 112-122. 


\section{Entry for the Table of Contents}

\section{FULL PAPER}

Heteroleptic bis(phosphinimino)methanide zinc complexes of the type LZnMe and LZnEt were synthesized by reactions of the corresponding bis(phosphinimino)methanes $\mathrm{H}_{2} \mathrm{C}\left(\mathrm{PPh}_{2} \mathrm{NR}\right)_{2}(\mathrm{R}=$ $\mathrm{SiMe}_{3}, \mathrm{Ph}, 2,6-i-\mathrm{Pr}_{2} \mathrm{C}_{6} \mathrm{H}_{3}$ (Dipp)) with $\mathrm{ZnR}_{2}(\mathrm{R}=\mathrm{Me}, \mathrm{Et})$ and characterized by heteronuclear NMR $\left({ }^{1} \mathrm{H},{ }^{13} \mathrm{C},{ }^{31} \mathrm{P}\right)$ and IR spectroscopy, elemental analysis and single crystal X-ray diffraction.
Melike Bayram, Sebastian Gondzik, Dieter Bläser, Christoph Wölper, Stephan Schulz*

Page No. - Page No.

Synthesis and Structure of Zinc Complexes containing sterically demanding

Bis(iminodiphenylphosphorane)methanides 
Additional Author information for the electronic version of the article.

Stephan Schulz: $\quad$ 0000-0003-2896-4488 


\section{DuEPublico}

Duisburg-Essen Publications online

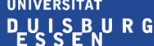

Offen im Denken

This text is made available via DuEPublico, the institutional repository of the University of Duisburg-Essen. This version may eventually differ from another version distributed by a commercial publisher.

\section{DOI: $\quad 10.1002 /$ zaac.201600196}

URN: urn:nbn:de:hbz:464-20201204-122605-7

This is the peer reviewed version of the following article: Bayram, M., Gondzik, S., Bläser, D., Wölper, C., Schulz, S.: Syntheses and Structures of Zinc Bis(phosphinimino)methanide Complexes. Z. Anorg. Allg . Chem. 2016, 642, 847-852, which has been published in final form at: https://doi.org/10.1002/zaac.201600196

All rights reserved. 